\title{
GOVERNANCE OF INTERNATIONALLY RECOGNISED, DECLARATION-BASED SUSTAINABILITY TOOLS, CASE FOR UNIVERSITIES IN TURKEY
}

\author{
*Pınar GOKCIN OZUVAR (Orcid ID: 0000-0002-2505-2216) \\ *Istinye University, Istanbul, Turkey
}

\begin{abstract}
The notion of universities being not only academic institutions carrying out research or teaching on sustainability but rather complementing this prior understanding, universities themselves being institutions with direct inter-relation with sustainability have resulted in re-thinking of sustainability governance.

Considerable amount of Turkish universities are taking this path as well and showing their institutional level commitment using various internationally recognised, declaration-based sustainability tools. This study tries to collate the institutional interest of Turkish universities based on this publically available presentation of commitment. Such tools can be listed as statements and policies, ratings and rankings and furthermore, standards and certificates. The results indicated that out of the selected tools that are commonly being used for this purpose, one-third of Turkish universities have shown the commitment to review their sustainability practices. Further analysis of relevance regarding ownership, age and geographical location bears no direct impact.
\end{abstract}

Keywords: declaration of commitment, sustainability, university, reporting, ranking, rating, standards, certificates

\section{INTRODUCTION}

The notion of sustainability governance in universities began taking form as of early 2000s when universities were put on stage as corporate bodies themselves with direct inter-relationship with the socalled sustainability pillars, environment, society and economy adding to the already existing expectations as research and education outputs on this multi-disciplinary topic (Allen, 2019). This change in the paradigm of sustainability in universities, initially covered many examples on one or more key aspects like bringing together students from different disciplines in collaborative tasks to design for sustainability (Welsh and Murray, 2003) or making sustainability a focus point in curriculum, research and organizational administration (Sterling, 2004); to in the quest of a sustainable campus, university 'greening' initiatives (Sharp, 2009).

Good governance starts with a good leadership and around the same time that sustainability focus started increasing in universities, the understanding towards leadership started to shift. Allen et.al (1999) reasoned that 'Leadership based on position and authority is inadequate for the challenges we face today. We need leadership which increases our capacity to learn new ways of understanding, defining, and solving the complex problems we are facing. ... Waiting for great individual leaders to guide and direct organizations as well as guarantee our safety and security is no longer possible.' This indicates that, as argued, leadership and sustainability has a post-heroic perspective, where leadership is about connecting people, places and purposes, rather than a person or position.

As universities began to grasp that institutional sustainability in the case of a university requires a centralised commitment to plan overreaching activities in all aspects of sustainability, from infrastructure and operations to research and education, from wellbeing to community impact, governance of these activities proved not easy as it included many stakeholders within the institutions with varying interests all yielding additional costs. Lozano, et.al. (2015) states on a study regarding views of universities on commitment for sustainability, academic leadership's commitment was a leading cause for signing a declaration, charter, or initiative, and implementing sustainable development. A similar study was carried 
out by Zahid et.al. (2020) on Integration, implementation and reporting outlooks of sustainability in higher education institutions (HEIs) with a focus on index and case base validation, universities analysed indicated inclination toward the broad agenda of sustainable development, but still, they lack integration, implementation and reporting of their sustainable practices. Another study revealed that problems observed in innovation in sustainable development in universities are mainly, lack of specific working groups, cultural and behavioural change, lack of financial resources, lack of engagement between municipalities and companies, and lack of reporting and accountability mechanisms (Avila, et.al., 2017)

Universities have different courses of actions and use various tools to present their declaration of commitment to sustainability. Below are the main tools that are being used to achieve this presentation. Most of these tools do not require an association with an internal sustainability body or a third party assessment and can be carried out by a representative for collecting and collating data from various departments in the university.

\section{Statements and Policies}

- Mission and vision statements: Although a somewhat out-dated, mission and vision statements are declarations where an organisation's purpose and outlook, both for those in the organization and for the public is expressed. Gurley, et.al, (2015) report findings from a study of graduate level, educational leadership students' familiarity with shared mission, vision, values, and goals statements and the perceived impact these concepts have on their practice as leaders and teachers in schools and findings revealed a limited ability to recall these statements and unless achieved as a result by internal meetings of university representative working groups on strategy, mission and vision statements do not go beyond well-articulated bunch of words that would not be directly relevant to the actual case. Mission vision statements can be part of the strategy documents and sometimes given on the website of the university for easy access.

- Policies: Policies issued by universities may be on various topics, i.e. environment, gender diversity. Similar to mission vision statements, issuing a university level policy on a topic, is efficient only if the policy is drafted or communicated by a group of stakeholders within the university, not only academics but also administrative staff, students, and even third-party operators. Policies are usually one page documents expressing the understanding of the university without giving any details on implementation as implementation can be time relevant whereas policies are deemed as perpetual documents on commitment by the university management.

One tool that needs to be reviewed here is the United Nations Global Compact (UN Global Compact) as it is a globally recognised commitment of certain principles from all kinds of organisations, including business, NGOs, NPOs and universities.

United Nations Global Compact (UN Global Compact) was launched in 1999 with the aim of assisting businesses in becoming responsible companies. It is a non-binding commitment for the 10 principles any responsible company should follow on Human Rights, Labour, Environment and Anti-Corruption. These principles are derived from the Universal Declaration of Human Rights, the International Labour Organization's Declaration on Fundamental Principles and Rights at Work, the Rio Declaration on Environment and Development, and the United Nations Convention Against Corruption. Companies can sign this commitment for the UN global Compact's 10 Principles and they are only required to submit a periodic report on the commitment (Bäumlisberger, 2019) and (The Ten Principles | UN Global Compact, 2020). The signatories are classified as business and non-business where the latter may include cities and municipalities, civil society and non-governmental organisations, labour unions, public sector organisations as well as academic institutions. Williams (2018) have emphasized the role of UN Global Compact on the impact for the paradigm shift to become responsible business, coining it as the 're-stroying the purpose of business'.

Signing of UN Global Compact does not require a pre-assessment on the relevant state of the organisation. However, expressing continued commitment is an important aspect and a Commitment of Engagement (CoE) report is required periodically. Each $\mathrm{CoE}$ should include a statement of continued support for the UN Global Compact and its ten principles, a description of the practical actions that the organization has taken as well as a measurement of outcomes. UN Global Compact CoEs are declaration based and there is no third party assessment and no need for additional evidence. All members' CoEs are publically accessible. 
Furthermore there are publically available 'expelled participants' and 'non-communicating participants lists establishing a transparent medium.

Principle 1: Businesses should support and respect the protection of internationally proclaimed human rights; and

Principle 2: make sure that they are not complicit in human rights abuses.

Principle 3: Businesses should uphold the freedom of association and the effective recognition of the right to collective bargaining;

Principle 4: the elimination of all forms of forced and compulsory labour;

Principle 5: the effective abolition of child labour; and

Principle 6: the elimination of discrimination in respect of employment and occupation.

Principle 7: Businesses should support a precautionary approach to environmental challenges;

Principle 8: undertake initiatives to promote greater environmental responsibility; and

Principle 9: encourage the development and diffusion of environmentally friendly technologies.

Principle 10: Businesses should work against corruption in all its forms, including extortion and bribery.

Exhibit 1: The Ten Principles of the UN Global Compact (The Ten Principles | UN Global Compact, 2020)

Another similar tool would be United Nations Principles for Responsible Management Education (PRME), with its 6 principles directed to Management Education.

Principle 1 | Purpose: develop the capabilities of students to be future generators of sustainable value for business and society at large and to work for an inclusive and sustainable global economy.

Values: We will incorporate into our academic activities, curricula, and organisational practices the values of global social responsibility as portrayed in international initiatives such as the United Nations Global Compact.

Method: create educational frameworks, materials, processes and environments that enable effective learning experiences for responsible leadership.

Research: engage in conceptual and empirical research that advances our understanding about the role, dynamics, and impact of corporations in the creation of sustainable social, environmental and economic value.

Partnership: interact with managers of business corporations to extend our knowledge of their challenges in meeting social and environmental responsibilities and to explore jointly effective approaches to meeting these challenges.

Dialogue: facilitate and support dialog and debate among educators, students, business, government, consumers, media, civil society organisations and other interested groups and stakeholders on critical issues related to global social responsibility and sustainability.

\section{Exhibit 2: 6 Principles of UN PRME (PRME, 2020)}

Although all the above stated principles could easily be transferred to other disciplines, PRME focuses on only one aspect of the institutional sustainability for universities, therefore is not one of those tools that govern the whole of the university.

\section{Ranking and rating}

Ranking and rating of companies have been mainstream for a while as well as the sustainability aspect. For the case of universities, A campus sustainability ranking system can be defined as a tool that evaluates the sustainability performance or expected performance of a higher education institution (HEI) and translates that evaluation into a general assessment that allows for comparison across similar institutions. Sustainability rankings categorize the performance of universities using a variety of criteria and indicators that can be grouped as: Green Campus and Buildings, Energy and Climate Change, Waste Management, Water Consumption, Transportation, Education for Sustainability, Stakeholder Participation sustainability governance and administration (Aina, et.al., 2019).

There are several national-level sustainable/green university ranking systems albeit on a smaller scale ranking of universities, 'People \& Planet' is one such example for UK where UK universities are ranked by students for environmental and ethical performance (People \& Planet University League, 2020). In USA, sustainability ranking/rating systems include Green Rating by Princeton Review, SIERRA Cool Schools, College Sustainability Report Card (CSRC)-currently suspended-, American College \& University Presidents' Climate Commitment (ACUPCC) and American Association for the Advancement of Sustainability in Higher Education (AASHE). 
There are regional practices however currently the two prominent internationally recognised ones are THE Impact and GreenMetric. Interest in both is increasing according to the given numbers of participating universities each year.

The IU GreenMetric World University Ranking claims to base its instruments on a broad philosophy that encompasses the three Es: Environment, Energy and Equity. IU GreenMetric was coined in 2010 with a common decision with an aim to provide the result of online survey regarding the condition and policies to Green Campus and Sustainability efforts in universities globally. Lauder et.al. (2015) suggest that GreenMetric is a significant ranking system and is designed as a practical entry-level tool for assessing global campus sustainability efforts.

IU GreenMetric is based on 6 main criteria as; 1) university landscape (setting and infrastructure), 2) electricity consumption (energy and climate change), 3) waste management, 4) water preservation, 5) green transportation for public, and 6) education and research related to sustainability. It also considers the size of the university, and its zoning profile, whether urban, suburban or rural. Data collection for the UI GreenMetric World University Ranking comes from online surveys sent to university administrators. The evidence for the data is collected by the use of a template with photos, declarations and other official documents.

Ragazzi et.al. (2017) reviewed the methodology of GreenMetric and stated that a lack of threshold for a defined sustainability, the lack of scoring bands, relativity of score, high sensitivity of the ranking, and incompleteness of the ranking, are major aspects in need of improvement to strengthen the ranking method.

The Times Higher Education Impact Rankings assess universities against the United Nation's Sustainable Development Goals aiming to evaluate performance regarding actual impact in respect to SDGs.

Although the methodology is still being updated, each university selects 3 of the UNSDGs that they feel confident in and then they have to also evaluate their performance for SDG17 'partnerships for goals'. Evidence need to be provided for all the information given in the mandatory questionnaire. Universities' scores are publically available in each selected SDG (Impact Ranking, 2020).

\section{Reporting}

Reporting of sustainability efforts can be part of other tools including ranking and rating, i.e. UI GreenMetric, UN Global Compact or THE Impact. In this section only those tools with direct purpose of reporting will be reviewed.

Global Reporting Initiative (GRI) is an independent international organization that promotes sustainability reporting since 1997 to help businesses and governments worldwide understand and communicate their impact on critical sustainability issues such as climate change, human rights, governance and social well-being. GRI has its own Sustainability Reporting Standards (GRI Standards) to issue a common format for reporting designed to be used as a set by any organization that wants to report about its impacts, and how it contributes towards sustainable development.

Among others following closely the evolution of GRI, Brown et.al (2009) and Milne and Gray (2013) has critiqued GRI reporting on its actual effectiveness resulting in continuous updating of the reporting standards over the years.

As of date, GRI provides modules on reporting called as standards and universal standards (foundation, general disclosure, management approach,), economic standards (economic performance, market presence, indirect economic impacts, procurement practices, anti-corruption, anti-competitive behaviour, tax), environmental standards (materials, energy, water and effluents, biodiversity, emissions, waste, environmental compliance, supplier environmental assessment), and finally Social Standards (employment, labor/management relations, occupational health and safety, training and education, diversity and equal opportunity, non-discrimination, freedom of association and collective bargaining, child labor, forced or compulsory labor, security practices, rights of indigenous people, human rights assessment local communities, supplier social assessment, public policy, customer health and safety, marketing and labelling, customer privacy, socioeconomic compliance) (Global Reporting Initiative, 2020). Reports from organisations are partially or fully disclosed via GRI website. Universities have also shown relatively lower 
interest in GRI and as of 2020, globally 14612 organisations have taken part in the GRI reporting mechanism with 61606 reports, of which 159 are universities with 456 reports.

\section{Certificates/Standards}

As in other tools discussed in this study, there are many standards or certificates involving only one aspect of the sustainability efforts within the university, i.e. building certificates LEED, BREEAM or these maybe only be focusing on a region, i.e. BS 8001:2017, British Standards on framework for implementing the principles of the circular economy in organizations.

Green Building certification or rating systems are systems which demonstrate the sustainability level of the building. The approach includes construction, design and operational phases and covers all relevant aspects to a green building, It can be applied to new buildings or retrofits. Globally recognised green building certificate examples are LEED and BREEAM. Although there are institutional barriers (Richardson and Lynes, 2007) green buildings and their relevant certification are commonly practiced in universities. As this type of certification only considers one aspect, it is not included in the scope of this study.

International Organization for Standardization (ISO) is an international non-governmental standardsetting body composed of representatives from various national standards organizations including Turkey (International Organization for Standardization, 2020). There are many standards on sustainability that can be used by universities, some of which are given below.

- ISO 26000 Social Responsibility

- ISO 20400 Sustainable Procurement

- ISO 37120 Sustainable development of Communities

- ISO 14046 Water Footprint

- ISO 50001 Energy Management

- ISO 14001 Environmental Management Systems

- ISO 14064 Greenhouse gases

\section{Networks}

Universities have been taking on the challenge to become sustainable institutions and cooperation between universities have evolved over the years yielding into many networks of varying scales from regional to global (Mothan-Hill, et.al., 2019). One of the prominent ones is the Global Alliance of Tertiary Education and Student Sustainability Network bringing together more than 30 higher education networks with the aim of making a collective impact which they cannot make alone. The Global Alliance was launched in 2015 brings together other regional as well as global networks. Below are those networks that are directly relevant to and formed by universities that aim institutional sustainability.

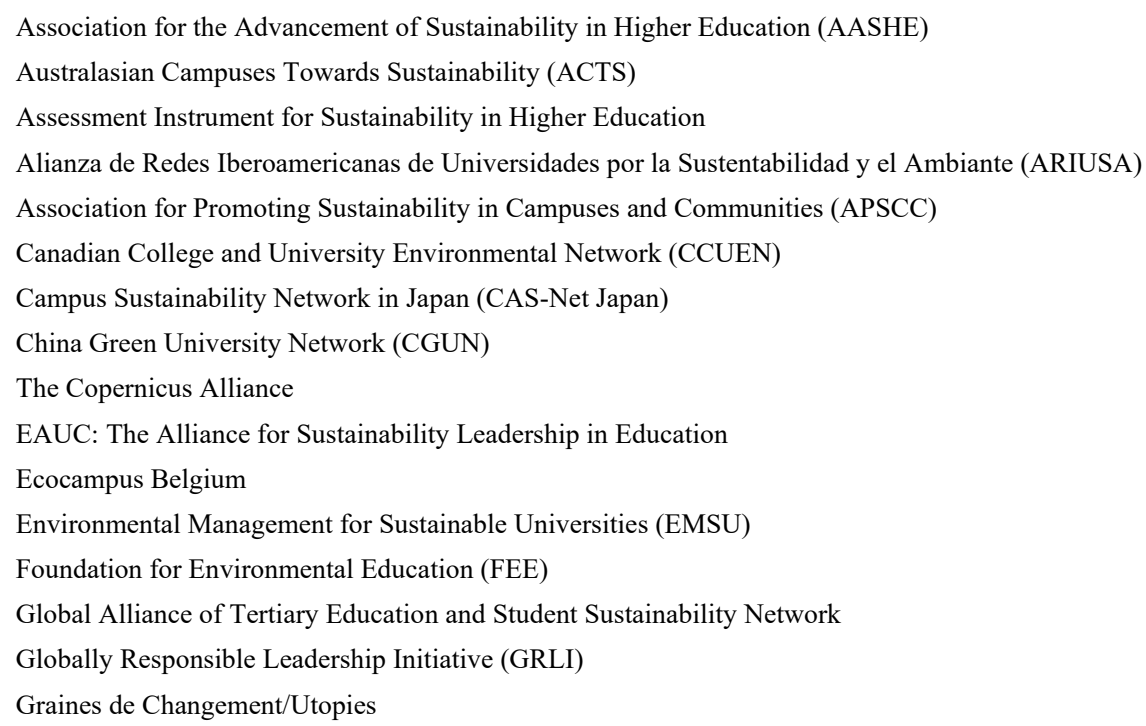




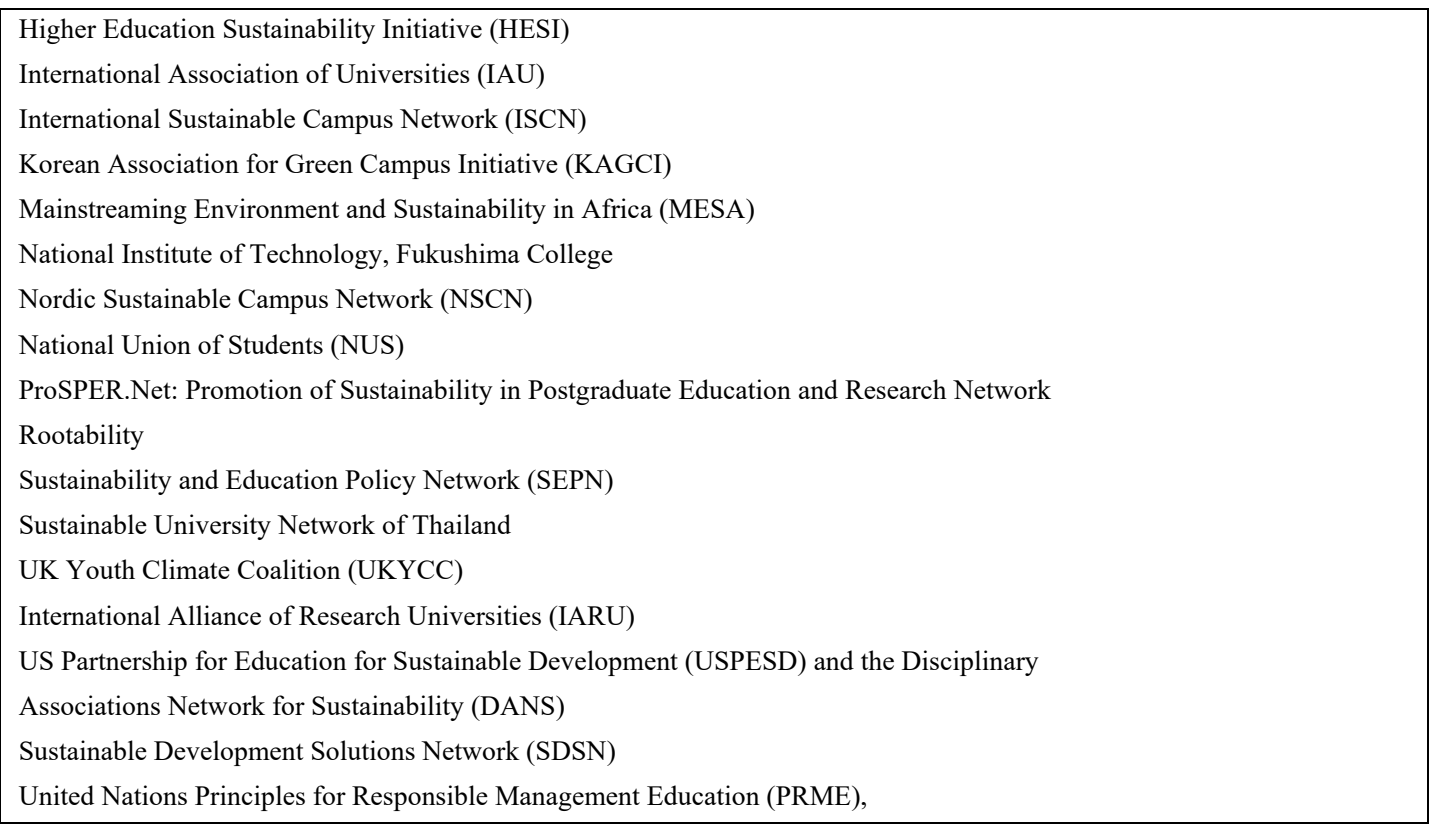

Exhibit 3: Global or regional networks that are directly relevant to and formed by universities that aim institutional sustainability. (Molthan-Hill, et.al., 2019).

Of the above, a prominent one is Sustainable Development Solutions Network (SDSN). SDSN brands itself as a global initiative for Unite Nations and aims to promote integrated approaches to implement the Sustainable Development Goals (SDGs) and the Paris Agreement on Climate Change, through education, research, policy analysis, and global cooperation (Sustainable Development Solutions Network, 2020). SDSN regards the effect of universities on the regional or global sustainable development rather than the institution's itself.

\section{METHODOLOGY AND RESULTS}

Screening all the previously mentioned tools for declaration-based commitment to sustainability, only those tools that possess the understanding below are included in the scope of the study.

- Global and not focusing on one region or country

- General take on institutional sustainability including infrastructure \& operations, research \& education, community relations and institutional well-being, i.e. not only green buildings.

- Including all stakeholders of a university and not focusing on just one group, i.e. not only students.

- Multi-disciplinary approach and not focusing on one discipline or subject, i.e. not only management education.

Reviewing all these mentioned tools for declaration-based commitment to sustainability yield the following results for the case of Turkish universities commitment. Only the tools that can be used as an institutional level -not one topic or aspect- were considered.

\begin{tabular}{|l|l|l|}
\hline Ranking & University & Overall \\
\hline 1 & Istanbul Technical University & 54 \\
\hline 2 & Erciyes University & 136 \\
\hline 3 & Middle East Technical University & 167 \\
\hline 4 & Ozyegin University & 173 \\
\hline 5 & Aksaray University & 227 \\
\hline 6 & Zonguldak Bulent Ecevit University & 254 \\
\hline 7 & Ege University & 259 \\
\hline 8 & Yildiz Technical University & 263 \\
\hline 9 & Hitit University & 282 \\
\hline
\end{tabular}


Journal of Global Strategic Management | V. 14 | N. 1 | 2020-June | isma.info | 019-030 | DOI: 10.20460/JGSM.2020.283

\begin{tabular}{|c|c|c|}
\hline 10 & Akdeniz University & 290 \\
\hline 11 & Cukurova University & 293 \\
\hline 12 & Afyon Kocatepe University & 305 \\
\hline 13 & Sabanci University & 324 \\
\hline 14 & Ondokuz Mayis University & 341 \\
\hline 15 & Bartin University & 348 \\
\hline 16 & Ankara University & 368 \\
\hline 17 & Cappadocia University & 392 \\
\hline 18 & Yeditepe University & 437 \\
\hline 19 & Dokuz Eylul University & 460 \\
\hline 20 & Anadolu University & 465 \\
\hline 21 & Inonu University Malatya & 468 \\
\hline 22 & Sivas Cumhuriyet University & 484 \\
\hline 23 & TOBB University of Economy and Technology & 492 \\
\hline 24 & Istanbul Sabahattin Zaim University & 496 \\
\hline 25 & Tokat Gaziosmanpasa University & 504 \\
\hline 26 & Bogazici University & 513 \\
\hline 27 & Düzce University & 525 \\
\hline 28 & Marmara University & 536 \\
\hline 29 & Ataturk University & 574 \\
\hline 30 & Galatasaray University & 576 \\
\hline 31 & Baskent University & 594 \\
\hline 32 & Süleyman Demirel Üniversitesi & 596 \\
\hline 33 & Kadir Has University & 601 \\
\hline 34 & Kto Karatay University & 607 \\
\hline 35 & Bolu Abant Izzet Baysal University & 609 \\
\hline 36 & Cankaya University & 615 \\
\hline 37 & Eskisehir Technical University & 617 \\
\hline 38 & Niğde Ömer Halisdemir University & 620 \\
\hline 39 & Bilkent University & 637 \\
\hline 40 & Igdir Universitesi & 667 \\
\hline 41 & Kilis 7 Aralik University & 677 \\
\hline 42 & Izmir University of Economics & 693 \\
\hline
\end{tabular}

Those tools that have found an interest are analysed, below are the ones that have received at least some interest from Turkish universities. However, as these are not representative, they are only briefly summarised.

- Global Reporting Initiative (GRI): Only 2 universities have taken part with single time reports dating back to 2011 and 2012. As GRI demands reporting to be updated annually, it is fair to say that the two universities are currently not pursuing this declaration-based tool.

- International Sustainable Campus Network (ISCN): ISCN is an organisation with a mission to provide an international forum to support higher education institutions in the exchange of information, ideas, and best practices for achieving sustainable campus operations and integrating sustainability in research and teaching (The International Sustainable Campus Network - ISCN, 2020). ISCN doesn't require reporting but only a commitment to the ISCN Charter by the university. At the time of this study, only 90 universities from 30 countries are members and only 4 universities in Turkey are members.

Three declaration-based tools are selected to understand the governance approach of Turkish universities' commitments on sustainability. All below selected tools require an institutional level, university-wide reporting on sustainability performance. Furthermore, these three are the only three tools that Turkish universities show an interest in participating. Those tools that a single university may have participated are not included. The Turkish universities that have taken part have also been analysed according to their date of establishment, geographical location and ownership.

\section{UI GreenMetric World University Ranking}


For the case of Turkish Universities, when the first set of data was collected from 96 universities globally and results announced for 2010, one Turkish university took part in the ranking followed by two Turkish universities in 2011. Almost 10 years later in 2019, globally 780 universities were listed of which 42 are Turkish Universities of which 30 are state-owned and 12 are foundation universities.

Exhibit 4 : UI GreenMetric results of Turkish Universities in 2019 (UI GreenMetric | World University Rankings, 2020)

The 2019 results indicate that only 4 universities are in the top quarter of the ranking. This may not be a direct sign for the sustainability of the universities but rather the lack of collating and presenting the right data in the required way. Data collection and accumulation in universities relevant to sustainability criteria required for IU GreenMetric ranking requires dedicated and institutionalised coordination within the university. Furthermore, analysing the list of participant universities, it can be stated that there is no direct relevance regarding date of establishment, geographical location and ownership status.

\section{United Nations Global Compact}

Turkish universities, have also recognised the importance of the commitment to UN Global Compact's 10 principles and although there is a longer list of academic members from Turkey, only 8 universities have been actively engaged. The date these universities signed the commitment for UN Global Compact, the status of the communication on Engagement is given below.

\begin{tabular}{|l|l|l|l|}
\hline & Joined on & Communication on Engagement & most recent COE \\
\hline Sabanci University & 29.01 .2007 & partial, only for business school & $2017-2019$ \\
\hline Koc University & 19.12 .2007 & university level & $2016-2018$ \\
\hline Istanbul Bilgi University & 23.06 .2009 & university level & $2014-2016$ \\
\hline Kadir Has University & 29.07 .2009 & university level & $2017-2018$ \\
\hline Izmir University of Economics & 15.11 .2012 & university level & $2018-2020$ \\
\hline Yasar University & 10.12 .2014 & university level & $2017-2019$ \\
\hline Ozyegin University & 21.12 .2018 & university level & due at the end of 2020 \\
\hline Yildiz Technical University & 14.03 .2019 & university level & due 2021 \\
\hline
\end{tabular}

\section{Exhibit 5: UN Global Compact Signatory Turkish Universities (Our Participants | UN}

$$
\text { Global Compact, 2020) }
$$

Of the 208 universities in Turkey, 8 is a minimal number although this doesn't indicate that remaining universities are not committed to these principles. This may only indicate lack of awareness as well as the lower priority level when it comes to international recognition regarding sustainable universities. Furthermore, analysing the list of participant universities, it can be stated that there is no direct relevance regarding date of establishment, geographical location and ownership status.

\section{THE Impact}

The Times Higher Education Impact Rankings assess universities against the United Nation's Sustainable Development Goals aiming to evaluate performance regarding actual impact in respect to SDGs. Although the methodology is still being updated, each university selects 3 of the UNSDGs that they feel confident in and then they have to also evaluate their performance for SDG17 'partnerships for goals'. Evidence need to be provided for all the information given in the mandatory questionnaire. Universities' scores are publically available in each selected SDG.

The first results were announced in 2019 and 450 universities from 76 countries including 19 universities from Turkey were listed. In its second year, 2020, the number of Turkish universities nearly doubled to 36 in line with the global number of 767. In 2020, 766 universities from 85 countries took part in THE Impact Rankings. 
Journal of Global Strategic Management | V. 14 | N. 1 | 2020-June| isma.info | 019-030 | DOI: 10.20460/JGSM.2020.283

\begin{tabular}{|c|l|l|}
\hline Rank & Name & Score \\
\hline $101-200$ & Abdullah Gül University & $75.4-83.3$ \\
\hline $201-300$ & $\begin{array}{l}\text { Bahçeşehir University, Hacettepe University, Koç University, Middle East } \\
\text { Technical University, Ozyegin University }\end{array}$ & $68.2-75.3$ \\
\hline $301-400$ & $\begin{array}{l}\text { Ankara University, Boğaziçi University, Erciyes University, Istanbul Bilgi } \\
\text { University }\end{array}$ & $61.5-68.0$ \\
\hline $401-600$ & $\begin{array}{l}\text { Atatürk University, Atılım University, Cukurova University, Ege University, Gazi } \\
\text { University, Gaziantep University, Istanbul Aydı University, Istanbul Gelişim } \\
\text { University, Izmir University of Economics, Kadir Has University, Sabanc1 } \\
\text { University, Tokat Gaziosmanpaşa University, Yeditepe University }\end{array}$ & $46.7-61.4$ \\
\hline $601+$ & $\begin{array}{l}\text { Anadolu University, Beykent University, Eskişehir Osmangazi University, Haliç } \\
\text { University, Istanbul Medipol University, Istanbul Technical University, Izmir } \\
\text { Institute of Technology, İstinye University, Karabük University, Marmara } \\
\text { University, Ondokuz Mayis University, Sakarya University, University of Turkish } \\
\text { Aeronautical Association }\end{array}$ & $9.5-46.6$ \\
\hline
\end{tabular}

Exhibit 6: Only a quarter of the Turkish Universities rank in the top half of the ranking (Impact Ranking, 2020)

Furthermore, analysing the list of participant universities, it can be stated that there is no direct relevance regarding date of establishment, geographical location and ownership status.

\section{CONCLUSIONS}

The following conclusions could be made from this research on the current status of governance based on declaration. In Turkey currently there are 62 universities engaged in showing commitment to one or more of the internationally recognised sustainability commitment and declaration tools where the university need to present an overall understanding for corporate sustainability defined beyond research but also including education, Corporate Social Sustainability, Infrastructure and Operations, etc. This is almost 30 per cent of all universities in Turkey, presenting an affirmative tendency in university sustainability.

Of the 62 universities, two-thirds are state-owned, which is perfectly in line with the 208 universities in Turkey and private and stated owned universities ratio is the same concluding that ownership status of universities has no direct effect on using the internationally recognised declaration-based sustainability tools.

Currently, the number of those universities that take part in one of the three tools discussed, are 42 in GreenMetric, 36 in THE Impact and 8 in UN Global Compact. Of these, only 4 universities are part of all 3 discussed tools and all these are private universities, all being less than 25 years old.

GreenMetric with 36 Turkish Universities is the most common tool that the universities prefer to use followed by 36 in THE Compact. This may be due to promotional activities of GreenMetric and THE Impact in the country since both require an evidence-based reporting which actually requires more effort in coordination for collecting the data, while UN Global Compact is more informal with only reporting without the need for further evidence to demonstrate proof. Not opting to signing the Global Compact's 10 principles, maybe associated with the lack of information about UN Global Compact among universities as it may be regarded as a tool for business rather than non-business.

Upon further investigation geographical distribution is homogenous with the country and the ratio is in line with the number of universities given in a city. Furthermore the age of the universities, had no direct correlation to the commitment as among the 62 universities, the date of establishment ranked form 1944 to 2018.

Future research needs to be carried out to understand the correlation between the inter-university governance structures, -whether there is a single delegated person or an institutional level governing bodyand practices on sustainability and the utilisation of internationally recognised declaration based university sustainability tools. Another issue regarding why Turkish universities are not pursing any of the other similar tools presented in this study, needs to be analysed by interviews with the universities. 


\section{REFERENCES}

Aina, Y.A., Abubakar, I.R., Alshuwaikhat, H.M. (2019). Global Campus Sustainability Ranking, Encyclopedia of Sustainability in Higher Education, 743-753, (C) Springer Nature Switzerland AG 2019, https://doi.org/10.1007/978-3-030-11352-0

Allen, S., (2019). Leadership and Sustainability, Encyclopedia of Sustainability in Higher Education, 1067-1081, (C) Springer Nature Switzerland AG 2019, http://doi.org/10.1007/978-3-030-11352-0

Allen, K.E., Stelzner, S.P., Wielkiewicz, R.M. (1999) The ecology of leadership: adapting to the challenges of a changing world. Journal of Leadership Organisation Studies, 5:62-82.

Ávila, L. V., Leal Filho, W., Brandli, L., Macgregor, C. J., Molthan-Hill, P., Özuyar, P. G., \& Moreira, R. M. (2017). Barriers to innovation and sustainability at universities around the world. Journal of Cleaner Production, 164, 1268-1278. https://doi.org/10.1016/j.jclepro.2017.07.025

Bäumlisberger, D. (2019). The United Nations Global Compact as a Facilitator of the Lockean Social Contract. Journal of Business Ethics, 159(1), 187-200. https://doi.org/10.1007/s10551-017-3721-1

Brown, H. S., de Jong, M., \& Levy, D. L. (2009). Building institutions based on information disclosure: lessons from GRI's sustainability reporting. Journal of Cleaner Production, 17(6), 571-580. https://doi.org/10.1016/j.jclepro.2008.12.009

Globalreporting.org. 2020. Global Reporting Initiative. [online] Available at: $<$ https://www.globalreporting.org/> [Accessed 30 May 2020].

Greenmetric.ui.ac.id. 2020. UI Greenmetric | World University Rankings. [online] Available at: $<$ http://greenmetric.ui.ac.id/> [Accessed 30 May 2020].

Gurley, D.K., Peters, G.B., Collins, L. et al. Mission, vision, values, and goals: An exploration of key organizational statements and daily practice in schools. Journal of Educational Change 16, 217-242 (2015). https://doi.org/10.1007/s10833-014-9229-x

ISO. 2020. International Organization For Standardization. [online] Available at: <https://www.iso.org/> [Accessed 30 May 2020].

ISCN. 2020. The International Sustainable Campus Network - ISCN. [online] Available at: $<$ https://international-sustainable-campus-network.org/> [Accessed 30 May 2020].

Lauder, A., Sari, R. F., Suwartha, N., \& Tjahjono, G. (2015). Critical review of a global campus sustainability ranking: GreenMetric. Journal of Cleaner Production, 108, 852-863.

https://doi.org/10.1016/j.jclepro.2015.02.080

Lozano, R., Ceulemans, K., Alonso-Almeida, M., Huisingh, D., Lozano, F. J., Waas, T., ... Hugé, J. (2015). A review of commitment and implementation of sustainable development in higher education: Results from a worldwide survey. Journal of Cleaner Production, 108, 1-18.

https://doi.org/10.1016/j.jclepro.2014.09.048

Milne, M. J., \& Gray, R. (2013). W(h)ither Ecology? The Triple Bottom Line, the Global Reporting Initiative, and Corporate Sustainability Reporting. Journal of Business Ethics, 118(1), 13-29. https://doi.org/10.1007/s10551-012-1543-8

Molthan-Hill, P., Erlandsson, L., Ndlovu, T., Patton, I., Goodwin, F., (2019). Global Alliance of Tertiary Education and Sustainable Development, Encyclopedia of Sustainability in Higher Education, 731-743, (C) Springer Nature Switzerland AG 2019, https://doi.org/10.1007/978-3-030-11352-0

People \& Planet. 2020. People \& Planet University League. [online] Available at: $<$ https://peopleandplanet.org/university-league $>$ [Accessed 3 May 2020].

PRME. 2020. PRME - About Us - Six Principles. [online] Unprme.org. Available at: $<$ https://www.unprme.org/about-prme/the-six-principles.php> [Accessed 30 May 2020].

Ragazzi, M., \& Ghidini, F. (2017). Environmental sustainability of universities: Critical analysis of a green ranking. Energy Procedia, 119, 111-120. https://doi.org/10.1016/j.egypro.2017.07.054 
Richardson, G. R. A., \& Lynes, J. K. (2007). Institutional motivations and barriers to the construction of green buildings on campus: A case study of the University of Waterloo, Ontario. International Journal of Sustainability in Higher Education, 8(3), 339-354. https://doi.org/10.1108/14676370710817183

Sharp, L. (2009). Higher education: The quest for the sustainable campus. Sustainability: Science, Practice, and Policy, 5(1).

Sterling S (2004) Higher education, sustainability, and the role of systemic learning. In: Corcoran PB, Wals AEJ (eds) Higher education and the challenge of sustainability: problematics, promise, and practice. Springer, Netherlands, 49-70

Times Higher Education (THE). 2020. Impact Ranking. [online] Available at:

$<$ https://www.timeshighereducation.com/rankings/impact/2020/overall\#!/page/0/length/25/sort_by/rank/s ort_order/asc/cols/undefined $>$ [Accessed 30 May 2020].

Unglobalcompact.org. 2020. The Ten Principles | UN Global Compact. [online] Available at:

$<$ https://www.unglobalcompact.org/what-is-gc/mission/principles $>$ [Accessed 30 May 2020].

Unglobalcompact.org. 2020. Our Participants | UN Global Compact. [online] Available at:

$<$ https://www.unglobalcompact.org/what-is-gc/participants> [Accessed 30 May 2020].

Unsdsn.org. 2020. Sustainable Development Solutions Network. [online] Available at:

$<$ https://www.unsdsn.org/> [Accessed 30 May 2020].

Welsh MA, Murray DL (2003) The ecollaborative: teaching sustainability through critical pedagogy. Journal of Management Education 27:220 )

Williams, O. (2018). Restorying the Purpose of Business: An Interpretation of the Agenda of the UN Global Compact. African Journal of Business Ethics, 12(2), 85-96. https://doi.org/10.15249/12-2-195

Zahid, M., Ur Rahman, H., Ali, W., Habib, M. N., \& Shad, F. (2020). Integration, implementation and reporting outlooks of sustainability in higher education institutions (HEIs): index and case base validation. International Journal of Sustainability in Higher Education. https://doi.org/10.1108/IJSHE10-2019-0308 